\title{
IMPLEMENTASI PROFESIONALISME GURU DALAM MEMOTIVASI BELAJAR SISWA DI SEKOLAH DASAR
}

\author{
Vitalis Djarot Sumarwoto *
}

\begin{abstract}
Professionalism seems to develop at all sectors in Indonesia today. Many efforts have been undertaken by the decision makers of education to pursue it. Among other efforts done by the authorities is the professional teacher certification. The implementation of professional teacher certification has basically referred to the Law No. 19, year 2005, on the National Education Standard; and the Governmental Regulation No. 74 year 2008 on Teachers, which suggest that teachers are obliged to have relevant academic qualification, competence and certification of educator. The objective of those regulations is only very prestigious i.e. to make them enhance qualified working experience within a certain interval of time. Hopefully, after they are certified professionally, they are able to encourage students to learn, especially for elementary students.
\end{abstract}

Key words: Professionalism, Motivating Learning

\begin{abstract}
Abstrak
Profesionalisme dalam bidang pendidikan di negeri ini dari waktu ke waktu memperoleh tempat untuk dikembangkan dan bahkan telah menjadi tuntutan. Berbagai cara ditempuh oleh para pengambil kebijakan di bidang pendidikan untuk mewujudkan tuntutan tersebut. Salah satu tuntutan tersebut adalah melalui program sertifikasi guru. Pelaksanaan program sertifikasi guru pada dasarnya mengacu antara lain pada Undang-Undang Nomor 19 Tahun 2005 tentang Standar Nasional Pendidikan dan Peraturan Pemerintah Nomor 74 Tahun 2008 tentang Guru yang mengamanatkan bahwa guru wajib memiliki kualifikasi akademik, kompetensi, sertifikasi pendidik. Tujuannya sangat mulia yaitu meningkatkan kualitas pengalaman berkarya dan berprestasi yang dicapai oleh masing-masing guru selama menjalankan tugasnya sebagai guru dalam interval waktu tertentu. Harapannya adalah setelah para guru memperoleh sertifikasi guru, sehingga disebut tenaga yang profesional, mampu memberi motivasi belajar siswa di sekolah, khususnya siswa sekolah dasar.
\end{abstract}

Kata kunci: Profesionalime, Memotivasi Belajar

* Vitalis Djarot Sumarwoto adalah Dosen Prodi BK dan Dekan FIP IKIP PGRI Madiun 


\section{A. PENDAHULUAN}

Dua kata kunci utama yang terkandung dalam tema tersebut di atas, yang perlu diperhatian, yaitu: profesionalisme dan motivasi belajar. Dua kata kunci tersebut sekaligus berfungsi sebagai variabel, yang akan memberi arah dalam tataran penulisan ilmiah, yang diharapkan mempunyai makna denotatif, sehingga tidak lagi muncul multi tafsir. Istilah "profesionalisme" menunjuk suatu kualitas sikap atau tingkah laku, yang menyatakan ciri suatu profesi. Profesionalime juga bisa dipahami sebagai hal yang mencirikan suatu profesional guru ketika mengimplementasikan jabatannya. Kata motivasi belajar dimaknai sebagai upaya memberikan dorongan positif dari seorang pendidik (guru) dalam kegiatan pembelajaran di sekolah. Dengan demikian dua kata kunci di atas menjadi acuan dalam keseluruhan pembahasan tulisan ini.

Guru (termasuk di sekolah dasar) yang profesional akan senantiasa mengacu kepada dimensi sebagaimana telah ditetapkan melalui antara lain Peraturan Pemerintah Nomor 19 Tahun 2005 tentang Standar Nasional Pendidikan dan Peraturan Pemerintah Nomor 74 Tahun 2008 tentang Guru. Peraturan Pemerintah tersebut mengamanatkan bahwa guru wajib memiliki kualifikasi akademik, kompetensi, dan sertifikat. Berkaitan dengan hal tersebut maka diterbitkanlah Permendiknas Menteri Pendidikan Nasional tentang sertifikasi guru dan dosen. Persyaratan sertifikasi guru pada Permendiknas Menteri Pendidikan Nasional Nomor 10 Tahun 2009 tentang Sertidikasi bagi Guru dalam Jabatan. Pada hakikat program sertifikasi guru dalam jabatan ini memuat empat komponen utama, yaitu: didaktik-metodik, kepribadian, sosial, dan profesional.

Komponen didaktik dimaksudkan bahwa seorang guru dituntut memahami teori-teori pendidikan, yang memberikan modal ketrampilan dalam aktivitas dan interaksi selama pembelajaran berlangsung. Sedang metodik merupakan internal guru dalam memilih dan menerapkan metode yang tepat yang digunakan dalam proses pembelajaran, sehingga dapat menimbulkan memotivasi belajar siswa. Prinsip dasar yang perlu dikembangkan adalah perwujudan bahwa pendukung utama terjadinya kegiatan pembelajaran, dan tercapainya pembangunan manusia Indonesia seutuhnya adalah pendidikan yang berkualitas. Penyelenggaraan pendidikan yang berkualitas tidak terlepas dari peningkatan profesionalisme guru dan sistem pengelolaan tenaga kependidikan, serta pengembangan kemampuan siswa untuk membantu diri sendiri dalam memilih serta mengambil keputusan demi mencapai tujuan hidup yang dikehendaki. Kualitas pendidikan ke depan tidak cukup dilaksanakan melalui tranformasi seperangkat ilmu pengetahuan, teknologi dan seni (ipteks). Kemampuan siswa seperti dikemukakan di atas tidak sekedar menyangkut kemampuan akademis, tetapi menembus perkembangan pribadi, sosial, dan kematangan intelektual, serta sistem nilai siswa. Pernyataan ini memberi petunjuk bahwa kualitas pendidikan menghantar siswa pada pencapaian standar akademis yang diharapkan dalam kondisi perkembangan diri siswa yang sehat dan optimal (Nurichsan, 2005).

Komponen kepribadian menunjuk kualitas pribadi guru sebagai modal dasar dalam melakukan interaksi dengan siswa melalui aktivitas belajar-mengajar. 
Kepribadian sering diartikan sebagai pola menyeluruh dari semua kemampuan, perbuatan, serta kebiasaan-kebiasaan seseorang, baik yang jasmani, mental, rohani, emosional, maupun sosial. Semuanya itu telah ditata sedemikian rupa, dalam caranya yang khas, di bawah pengaruh lingkungan dari luar (Heuken, 2003). Pola menyeluruh itu terwujud dalam perilaku dan dalam usaha menjadi manusia sebagaimana dikehendakinya (Vitalis, 2008: 1). Kepribadian bukanlah sekedar tumpukan unsur atau sifat-sifat yang terpisah. Kepribadian bukan seperti bangunan rumah yang sekedar tumpukan batu bata, semen, dan lain-lain. Kepribadian seharusnya merupakan kesatuan yang indah dan harmoni (Vitalis, 2008: 13).

Komponen sosial dalam implementasinya menunjuk aspek kemampuan dalam menciptakan dan membangun komunikasi yang intensif antara guru dengan siswa. Komunikasi yang dibangun sebaiknya sebaiknya menembus teman sejawat maupun dalam konteks pembelajaran di sekolah sebagai perwujudan profesionalisme guru. Pernyataan di atas mengandung suatu pengertian bahwa guru memiliki peranan penting dalam menjalankan profesionalismenya.

\section{B. PEMBAHASAN}

\section{Guru dan Peranannya}

Dalam keseluruhan proses pendidikan dan pembelajaran di kelas/sekolah, guru merupakan elemen kunci. Dalam tugasnya sebagi pendidik guru banyak sekali memegang berbagai jenis peranan yang sadar atau tidak sadar, mau atau tidak mau wajib dilaksanakan oleh seorang guru yang profesional. Peranan guru yang profesional ini meliputi berbagai tingkah laku (sebagai proyeksi sosial dan kepribadian) baik dalam aktivitas di sekolah maupun di luar sekolah. Guru yang profesional adalah sosok individu yang berhasil dalam mengimplementasikan peranannya dengan sebaik-baiknya. Hal tersebut dapat diartikan bahwa guru dapat menunjukkan suatu pola perilaku yang sesuai dengan kabatannya, dan dapat diterima oleh lingkungan kerja dan masyarakatnya. Beberapa jenis peranan guru dapat diuraikan sebagai berikut.

a. Guru sebagai Mediator Sekolah

Guru sebagai moderator belajar mengandung suatu pernyataan bahwa guru sebagai perantara dalam keseluruhan proses belajar secara keseluruhan. Guru adalah yang menyelenggarakan perilaku belajar siswa, dan bertanggung jawab terhadap hasil aktivitas belajar tersebut, melalui proses interaksi belajar-mengajar. Guru merupakan salah satu faktor penting yang diharapkan mempengaruhi keberhasilan belajar siswa. Oleh karena itu maka seorang guru dalam operasionalnya di sekolah harus menguasai materi, prinsip-prinsip belajar, mampu menciptakan belajar yang baik.

\section{b. Guru sebagai Penegak Disiplin}

Pepatah mengatakan bahwa disiplin diri menjadikan disiplin dari luar tidak diperlukan. Tugas yang melekat pada diri seorang guru adalah memo-tivasi dirinya dalam penegakan disiplin, baik di sekolah maupun di luar sekolah. Guru sebaiknya menjadi teladan bagi terlaksananya penegakan disiplin. 
c. Guru sebagai Administrator dan Manajer Kelas

Seorang guru dikenal sebagai pendidik dan pengajar, yang berperan sebagai petugas administrasi dan sekaligus sebagai manajer kelas. Sebagai administrator, guru bertugas menyelenggarakan program pendidikan dengan sebaik-baiknya. Berbagai aspek yang menyangkut kelancaran jalannya pembelajaran merupakan tanggung jawab guru. Dalam konteks ini seorang guru berkewajiban mengambil bagian dalam hal perencanaan kegiatan pendidikan (planning), mengatur dan menyusun berbagai aspek dalam pendidikan (organizing), mengarahkan kegiatan-kegiatan berbagai aspek dalam pendidikan (directing), melaksanakan segala rencana dan kebijaksaan pendidikan (actuating), dan menyusun beaya pendidikan (budgeting), dan mengawasi serta menilai kegiatan-kegiatan pendidikan (controling).

Semua ini dilaksanakan oleh seorang guru sebagai implementasi profesionalismenya. Sebagai manajer kelas guru merupakan penguasa utama yang mempunyai tanggung jawab terhadap kelancaran kelancaran program pendidikan dan pengajaran. Guru ketika di kelas berperan sebagai pengelola, pemimpin siswa dalam keseluruhan aktivitas pembelajaran, karena akan menentukan keberha-silan sekolah secara keseluruhan. Guru secara profesional sebaiknya menga-tur dan mengkoordinir hasil belajar dengan sebaik-baiknya.

\section{Motivasi adalah Salah Satu Unsur Dinamis dalam Belajar}

Winkel mengartikan motivasi belajar pada dasarnya perlu memahami pengertian "motif" terlebih dahulu (Hastuti, 2006). Motif adalah daya penggerak di dalam subyek (siswa) untuk melakukan aktivitas-aktivitas tertentu demi mencapai tujuan. Motif merupakan suatu kondisi internal, yang disebut disposisi atau kesiapsiagaan. Sehingga dapat disimpulkan motivasi itu pada dasarnya adalah daya penggerak yang telah menjadi aktif pada saat-saat ada kebutuhan untuk mencapai suatu tujuan yang sangat dirasakan atau dihayati. Jadi motivasi belajar ialah keseluruhan daya penggerak di dalam diri subyek (siswa) yang menimbulkan aktivitas belajar, yang menjamin kelangsungan dari aktivitas belajar itu, yang memberikan arah pada aktivitas belajar itu, maka tujuan yang dikehendaki oleh subyek (siswa) tersebut tercapai. Dikatakan "keseluruhan", karena biasanya ada beberapa motif yang bersama-sama menggerakkan seseorang untuk belajar. Motivasi belajar merupakan faktor psikis, yang bersifat nonintelektual. Peranannya yang khas adalah dalam hal gairah (semangat) belajar. Seseorang yang bermotivasi kuat akan mempunyai banyak energi untuk melakukan kegiatan belajar.

Rocman dan Musa menyatakan bahwa berbicara tentang motivasi akan lebih jelas apabila dikaitkan dengan unsur-unsur yang mengelilingi motivasi itu sendiri (Gino dkk., 1984: 22). Unsur-unsur yang dimaksud adalah: dorongan (drive), kebutuhan, motif, tindakan dan tujuan. Unsur-unsur itu saling berkaitan secara fungsional, satu dan lainnya saling berpengaruh. Secara skematis dapat diilustrasikan pada Gambar 1. 


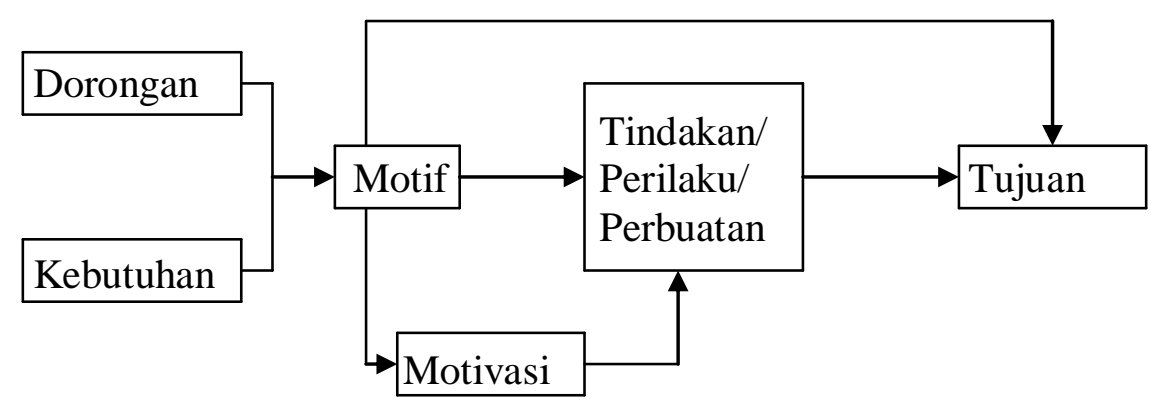

\section{Gambar 1 Skematis Motivasi}

Berdasarkan Gambar 1 dorongan dalam diri subyek diperlukan untuk mempertahankan diri. Dorongan muncul ketika ada ancaman, yang dapat berupa ketidak seimbangan fisiologis maupun psikologis. Dorongan-dorongan ini pada gilirannya berubah menjadi suatu kebutuhan, diperlukan untuk menyeimbangkan fisiologis dan psikologis. Dari dorongan dan kebutuhan tersebut kemudian menimbulkan keadaan siap melakukan aktivitas, yaitu memenuhi kebutuhan dan mencapai tujuan.

\section{Upaya-upaya Guru memotivasi Belajar Siswa}

Banyak yang dapat dilakukan oleh guru dalam upaya untuk memotivasi belajar siswa, dapat dikemukakan sebagai berikut:

a. Pernyataan penghargaan guru secara verbal

Pernyataan verbal terhadap perilaku yang baik atau hasil kerja (belajar) yang baik; misalnya: "Bagus sekali....". Oke, ternyata jika kamu rajin merangkum hasilnya......".

b. Menggunakan nilai ulangan sebagai pemacu keberhasilan

Pengetahuan siswa yang kurang baik merupakan cambuk untuk meningkatkan motivasi belajar siswa. Terhadap siswa yang kurang berhasil guru dapat memberikan dorongan atau stimulan agar siswa belajar lebih giat lagi. Tumbuhkan rasa ingin tahu pada diri siswa dapat digunakan untuk memotivasi belajar siswa. Rasa ingin tahu ini dapat dimunculkan oleh suasana yang mengejutkan, keragu-raguan, atau mengejutkan.

c. Menggunakan materi yang sudah dikenal siswa sebagai contoh belajar

d. Menuntut siswa menggunakan hal-hal yang telah dipelajari sebelumnya sebelumnya.

Hal ini dapat memotivasi siswa dan menguatkan pemahaman hasil belajar

e. Guru sebaiknya jangan pelit pujian

Pujian yang diterima siswa dari guru sangat besar manfaatnya dalam memotivasi belajar siswa. Pujian tidak senantiasa dikaitkan dengan keberhasilan siswa dalam mengukir prestasi belajar. 
f. Menata lingkungan belajar

Teori Kognitif menurut Degeng (2001) menegaskan bahwa penataan lingkungan belajar yang bebas dalam belajar/pembelajaran dapat dimanfaatkan sebagai sarana memotivasi belajar siswa. Lebih lanjut Degeng mengemukakan hanya di alam yang penuh dengan kebebasan siswa dapat mengungkapkan makna yang berbeda dari hasil interpretasinya terhadap segala sesuatu yang ada di dunia nyata. Kebebasan menjadi unsur yang esensial dalam lingkungan belajar. Kegagalan atau keberhasilan, kemampuan atau ketidakmampuan dilihat sebagai interpretasi yang berbeda yang perlu dihargai. Kebebasan dipandang sebagai penentu keberhasilan belajar. Siswa adalah subyek belajar yang harus mampu menggunakan kebebasan untuk melakukan pengaturan diri dalam belajar. Kontrol belajar dipegang oleh siswa. Tugas utama guru adalah membelajarkan bagaimana siswa harus belajar (learning how to learn).

g. Menciptakan sekolah sebagai rumah kedua bagi siswa

Sekolah merupakan pendidikan formal, setelah pendidikan dalam keluarga. Karena keterbatasan keluarga dalam mendidik anak-anaknya, maka anak dipercayakan kepada pihak sekolah. Mengingat hal ini, maka jadikanlah seolah menjadi rumah kedua bagi siswa.

h. Menghindari memberi label (lebeling) atau materai pada siswa

Setiap siswa adalah individu yang berperilaku sesuai dengan individualisasinya, karena itulah kekhasan siswa tersebut. Guru dapat menangkap kekhasan siswa itu dalam usahanya untuk memotivasi siswa dalam hidupnya.

i. Hindarilah menyindir atau mengkritik

Perilaku menyindir siswa hendaknya dihindari oleh para guru, yang memiliki tanggung jawab terhadap proses pendewasaan siswa. Demikian pula hendaknya kritikan terhadap siswa (terutama yang kurang berprestasi) sedapat mungkin tidak menjadi sikap guru di sekolah.

j. Mengembangkan rasa aman siswa

Bagi banyak orang (siswa) yang paling aman mereka dambakan adalah untuk dilihat dan diterima apa adanya (acceptance) oleh para guru di sekolah, sebuah hasrat untuk diperlakukan dengan baik tanpa syarat, penuh bela rasa, pengertian, dan rasa hormat sebagai individu; untuk diberi kebebasan, rasa aman, privasi, dan rasa kedekatan.

k. Cinta guru kepada siswa bukanlah cinta iming-iming

Cinta iming-iming identik dengan bersyarat. Sebentuk cinta bersyarat yang lebih menyakitkan dan lebih merusak motivasi belajar siswa adalah cinta imingiming (dangling carrol love), dimana cinta dijanjikan oleh guru dan diletakkan di tempat yang seolah-olah bisa diraih, tetapi tak pernah benar-benar terjangkau. Cinta seperti ini sebaiknya dieliminir, karena bukan perwujudan profesionalitas guru. 
1. Hindari menciptakan manusia pelaku

Sadar atau tidak sadar setiap siswa pasti ingin mencintai dan dicintai. Cinta hasil dan cinta iming-iming memiliki aspek yang patut disayangkan, yaitu guru menyatakan kepada siswa bahwa mereka hanya pantas dicintai jika memenuhi harapan dari guru. Cinta bersyarat ini menciptakan siswa menjadi manusia pelaku (baca: robot) dimana perasaannya mengenai diri sendiri selalu dikaitkan dengan prestasinya. Cinta yang menumbuhkan motivasi mengandung suatu pengertian bahwa interaksi antara hasil dan harga diri yang harus menjadi dasarnya. Dan menunjukkan hasil yang baik pada mata pelajaran yang diberikan. Pernyataan seperti ini tidak akan menimbulkan motivasi belajar siswa di sekolah.

m. Perspektif tentang kesalahan

Cara siswa memahami makna kesalahan akan berdampak dramatis bagi kemampuan siswa untuk meningkatkan diri dan berprestasi. Giovanni mengemukakan kesalahan merupakan kenyataan hidup (Vitalis, 2005), yang penting adalah reaksi terhadap kesalahan. Sayangnya, guru sering mengkomunikasikan pesan yang sangat berbeda. Kesalahan adalah sesuatu yang berakibat buruk bagi siswa, sehingga siswa tidak berani berbuat kesalahan. Mengharapkan siswa tidak melakukan suatu kesalahan berarti memberi siswa sebuah pesan yang kejam dan keliru mengenai hidup. Pengharapan ini membuat sebuah standar yang takkan bisa dipenuhi.

n. Menanggapi kesulitan secara positif

Jalan memotivasi siswa tidaklah selalu mulus, tetapi penuh rintangan, kemunduran, dan perjuangan. Kesulitan ini dapat bersifat eksternal dan internal. Namun yang bersifat internal ini antara lain berhubungan dengan hilangnya motivasi dan hasrat tidak menyerah. Cara siswa menanggapi berbagai tuntutan ini akan menentukan batas-batas prestasi dan kebahagiaan yang akhirnya akan siswa peroleh. Tugas guru dalam hal ini adalah sebagai fasilitator, motivator, dan advokator.

\section{PENUTUP}

Lakon guru sebagai motivator yang handal membawa konsekuensi logis terutama bagi guru yang bersangkutan. Seorang guru dalam kiprahnya dituntut untuk senantiasa mampu memotivasi diri untuk pengembangkan diri, memiliki kepekaan terhadap tuntutan zaman, memiliki kemampuan dalam self-inovation, yang kesemuanya ini pada akhirnya akan mendukung profesionalisme guru dalam mengimplementasikan jabatannya, khususnya di sekolah. Guru diharapkan senantiasa mencerminkan sosok individu yang tegar, genuin, help fulness, mampu menerima siswa apa adanya, sesuai dengan kekhasan masing-masing. 


\section{DAFTAR RUJUKAN}

Abraham, A. 2005. Mengupas Kepribadian Anda. Cari Tahu Karakter Anda. Jakarta: PT Bhuana Ilmu Populer.

Deci, E.L, Koestner, R., dan Ryan, R.M. 1999. A Meta-Analitic Review of Experiments Examining the Effects of Extinsic Reward on Intrinsic Motivation. American Psychologis.

Degeng, N. S. 2001. Pokok-pokok Pikiran Revolusi Belajar-Mengajar. Makalah Seminar Teknologi Universitas Negeri Malang.

Heuken, A. 2002. Tantangan Membina Kepribadian. Pedoman untuk Mengenal dan Membina Diri. Jakarta: Cipta Loka Carita.

Nurihsan, A.J., dan Sudianto, A. 2005. Manajemen Bimbingan dan Konseling di Sekolah Menengah. Jakarta: PT Gramedia Widiasarana Indonesia.

Nuttall, E.V., dan Nuttall, R.L, 1976. Parent-child Relationship and Effective Academic Motivation. Journal of Psychology.

Petersen, L 2004. Bagaimana Memotivasi Anak Belajar. Jakarta: PT Gramedia Widiasarana Indonesia.

Taylor, J. 2005. Memberi Dorongan Positif pada Anak. Jakarta: PT Gramedia Pustaka Utama. 